\title{
Causes and Impacts of Conflicts in Construction Projects: A Viewpoint of Kenya Construction Industry
}

\author{
Samuel Kiilu Mbatha
}

\begin{abstract}
Construction projects are predisposed to conflicts. This is attributed to the multiplicity of personnel handling the various phases of the projects. Empirical evidence from previous studies shows that if not properly managed, conflicts affect among others, the project's productivity loss, inadequate time and cost performance levels, loss of profit, and damage in business relations. Identifying the significant causes and major potential impacts of conflicts is crucial to reducing the risk of conflict occurrence in projects. Hence, this study was focused on explaining the classification of conflicts, identifying and assessing their causes and impacts in construction projects in Kenya grounded on the perception of project consultants and contractors. To accomplish the study objectives, a questionnaire was designed to collect data on the experiences of construction professionals on the causes and impacts of conflicts during project implementation. A total of 122 consultants and contractors provided responses, which were analyzed. A total of 42 significant causes of conflicts in the Kenyan context were identified. Based on the survey results, delay in progress payments by the client was identified as the most significant cause of conflicts, followed by poor site management and supervision. The survey also revealed that conflicts can emerge from any of the stakeholders, with contractors contributing the most, accounting for 14 of the 42 conflict factors identified. The study ranked the impacts of these conflicts using the Relative Severity Index (RSI). The results indicated that the biggest impact of conflicts on construction projects is the loss of profitability and perhaps business viability, and delays in project delivery. Expert opinions regarding the best practices and strategies for improving project harmony through effective conflict management were reviewed and grouped into five classes namely; project documentation, stakeholder involvement, value-based procurement, and adoption of ICT. It is concluded that the project manager should develop his leadership role by the adoption of these strategies so that he can use his position to effect positive conflict management on his team members. Furthermore, during the life cycle of the construction project, special attention should be given to the identified cause factors to avoid or effectively manage conflicts. These results, taken together, support clear guidelines on the need for proactive financial obligation on the client-side, as well as the hiring of experienced project professionals. Implementing these suggestions would reduce the risk of conflicts arising during building projects.
\end{abstract}

Keywords: Conflict, Conflict Management, Construction Industry, Project Harmony.

Manuscript received on March 19, 2021.

* Correspondence Author

Samuel Kiilu Mbatha*, Department of Construction Management, Jomo Kenyatta University of Agriculture and Technology (JKUAT), Juja, Kenya. Email: $\underline{\text { skiilu@jkuat.ac.ke }}$

(c) The Authors. Published by Blue Eyes Intelligence Engineering and Sciences Publication (BEIESP). This is an open access article under the CC BY-NC-ND license (http://creativecommons.org/licenses/by-nc-nd/4.0/)

\section{INTRODUCTION}

The construction sector, worldwide, forms one of the significant drivers of economic development. In Kenya, the sector is a fundamental pillar in the achievement of the country's vision 2030 through its ability in job creation. Kingsley (2015) states that the complex and lengthy process of designing and building construction projects is characterized by unending conflicts. Leong et al. (2014) affirm that conflict becomes an ordinary occurrence in construction projects due to its intricate and complex nature, as well as the involvement of different participants within the project cycle. As established through review of literature, any construction project involves the engagement of a wide range of professionals whose roles, responsibilities, and level of involvement during the project implementation are dictated by the procurement method adopted. According to Chigangacha \& Haupt (2018), the construction industry's existence is imputed to a co-existence of the developer and contractor. This indicates that the performance degree of conflict management is streamlined to meet the parties' expectations and objectives.

Several scholars, including and Agwu (2013) and Vaux, (2014), believe that conflict is an unavoidable by-product of organizational operations. Agwu (2013) attributes this to be caused by the fact that despite the project team drawing from different backgrounds and knowledge in different fields, each project participant has their own individual objectives, views, and perspectives which at times could conflict with the general objectives of the organization. According to Mbatha, Alkizim, et al. (2021), whenever these conflicts are not actively and positively resolved at the right level, the consequences are; a perception of threat to one's goals by another person, blame game amongst the project participants, and low management success. This is affirmed in Agwu (2013) who argues that project Participants within the group embrace their own individual ambitions and block any persuasions from outside, in fear of discordance based on these contradictory positions. Mbatha et al. (2021) cites conflicts as one of the variables subverting project success as they can be time depleting, costly and unpleasant in that they can destroy the relationship amongst the project participants and also add to the cost of the contract, bogging down and impeding the smooth implementation of projects.

Published By:

Blue Eyes Intelligence Engineering

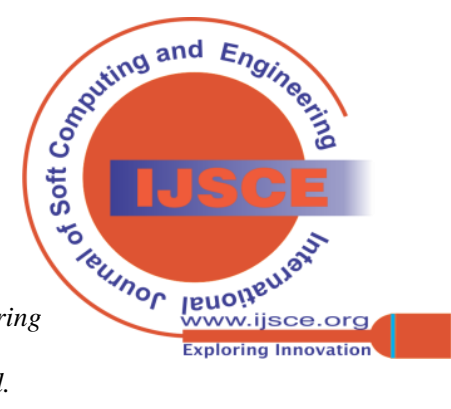


This prevalence of conflicts in construction building projects indicates that the current approach to Conflict management practice amongst project participants is not effective enough, as construction industry players have unassumingly amalgamated underlying management project execution. Therefore, there is a need to understand the nature and areas from which conflicts arise to design a methodological framework that minimizes or mitigates these conflicts. This study contributes to the research and practice community by covering the issues on which conflicts amongst participants in a project occur, the nature of the conflicts, and the effects on building projects in Kenya.

\section{LITERATURE REVIEW}

\section{A. Conflict and Its Spectrum}

Conflict has been defined as the impression that a party's goals, interest or objectices are being handicapped by another party, whether actual or imagined, and the degree of conflict is guided by the extend of a party's commitment to a goal. (Mitkus and Mitkus, 2014). Yale, D.J. and Hardcastle (2003) apply a continuum setting to define conflicts by combining the words "claim," "dispute," and "conflict." They begin by describing claim as "a clear affirmation or declaration of a legal right to money, assets, or a reward imposed by law, which can be built under the terms of the contract; for violation of contract, negligence in common law, or on the quasi-contractual justification". They then describe dispute as an unresolved claim, and then define conflict by integrating the claim and dispute meanings with the sociological definitions of conflict given above arguing that conflicts emerge where there is a misalignment of need, and one individual perceives that this incompatibility is interfering with the satisfaction of that person's needs.

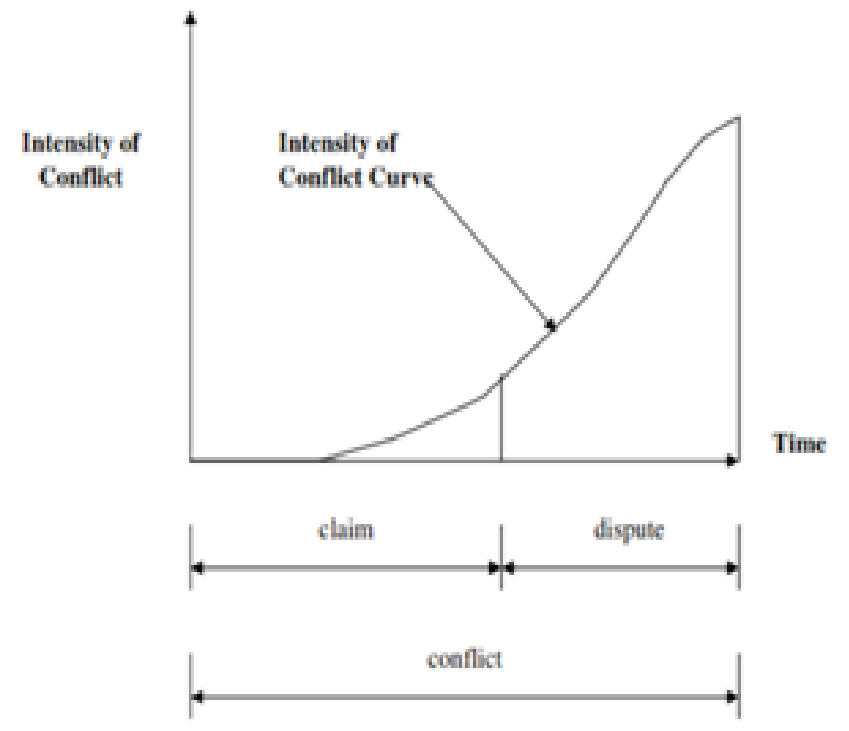

Figure 1: The spectrum of conflicts Source: (Yale, D.J. and Hardcastle, 2003)

The increasing potency, strength, and intensity of the conflict in its progress through the various phases of a claim are indicated by the intensity of the curve. expertise which emphatically impacts relations during the

\section{CLASSIFICATION AND PHENOMENON OF CONFLICTS}

\section{A. Types of Conflicts}

The effect of conflict is a highly subjective measure according to which party's point of view is taken. According to, Simmons \& Peterson (2000), conflicts arises in three levels;

(i) Intrapersonal conflict- This is the conflict that takes place inside the individual. Intrapersonal conflict arises where an organizational participant is expected to execute duties and responsibilities that are inconsistent with his or her expertise, desires, goals, and beliefs.

(ii) Interpersonal conflict- This is also referred to as dyadic conflict. It's the conflict experienced between individuals in the same hierarchical level in the organization or unit for example roommates, co-workers, etc.

(iii) Intra-group conflict- This refers to conflict between two or more parties of the same command, team or, organisation.

According to Simons and Peterson (2000), these three levels of conflict can generally be divided to form two major categories, each with a different effect on project execution: relationships and task conflicts. Relationship conflicts, also known as emotional conflict, focus on interpersonal incompatibilities, which have little to do with the task, and frequently involve emotional stress over personality, attitude, power, trust, strength, respect, trust or gratitude, etc., and is viewed as dysfunctional at all levels in an organization structure, while task conflict, also known as cognitive or substantive conflict centres on task-oriented disparity, and stems from apparent differences of viewpoints or opinions on the task at hand. Task conflict is viewed as beneficial at appropriate levels as it can result in increased decision quality, team cohesion, and cohesion (Vaux, 2014).

\section{B. Functional and Dysfunctional Conflict Phenomenon}

This is the event that views conflict as either a disease or an important substance in the organization. Vaaland and Häkansson (2003) consider the phenomena from two different perspectives. The first phenomenon views conflict as a negative influence in organizations causing disruptions, dissociations, and dysfunctional effects. In this perspective, there is fear that trivial coherence in the organization operations can evolve into destructive conflict, therefore the need to resolve the conflict and to mitigate or minimize its deleterious consequences. In the second perspective, conflict is viewed as a positive view and considered to bring a positive result to the conflicting parties. Positive outcomes of functional conflict include; Conflicting parties' understanding of the issues at stake, enhancement of working conditions as a result of achieving solutions collectively, Solving issues together to boost overall motivation in the organization team, and enabling innovations, progress and improvements within an organization. Vaaland \& Häkansson (2003) use a metaphor of two axes to explain how conflict can be functional or dysfunctional.

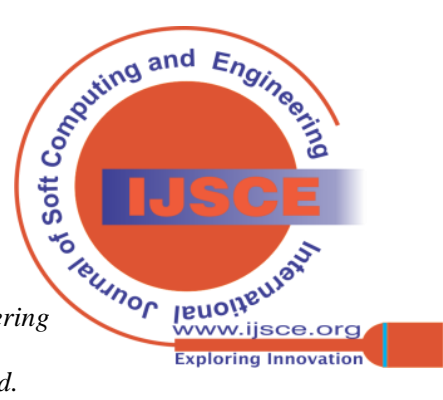


The first axis represents the degree of collaboration between two groups, while the second represents the degree of conflict in business relationships. The Figure illustrates that by perceiving collaboration and conflict as two dimensions, four different combinations can be established.

\begin{tabular}{l|l|l|}
\cline { 2 - 3 } Degree & \multirow{2}{|l|}{ NICE } & WELL DEVELOPED \\
\cline { 2 - 3 } Collaboration & MARGINAL & HOSTILE \\
\cline { 2 - 3 } & &
\end{tabular}

Figure 2: Functional and dysfunctional conflict model Source: (Vaaland and Häkansson, 2003)

Some degree of conflict in an organization is not only inescapable but also desired, as conflict can be a catalyst and an outcome of transformation. (Jaffar et al., (2011). In order for the top management in an organization to keep open to innovations and new ideas and keep the operation on track, they must rely on functional conflicts. Second, dysfunctional toxic conflict types impair organizational performance. Managers should seek their eradication. Jaffar et al. (2011) further assert that the classification of conflict as either functional or dysfunctional depends on the value systems used. Researchers conclude that conflict may be either functional or dysfunctional and is not necessarily either one. This implies that the effects of conflict must be evaluated relative to some set of values.

\section{Conflict in Organizations}

Organizational conflict is defined as an open battle or interference between two or more groups in an organization, between two or more organizations (Rahim, 2001). Among the earlier theories on organizational conflict are the works of Marx, who looked at organizational conflict based on social contradiction, class struggles, and control Marx and Engels in Rahim (2001). Among these theories, however, none gives a model that can explain the conflict in organizations thus the need to have an understanding of the dynamics of conflicts in organizations with each organization having a complexity of definition, a good example being the construction industry.

\section{Horizontal conflicts}

Organizational conflict involves interpersonal conflicts with subordinates or superiors, as well as intergroup within different divisions of an organization (Simmons and Peterson, 2000; Rahim, 2001). Horizontal conflict occurs between team members of the same hierarchical level. (Stojkovic et al., 2003). Horizontal conflicts manifest themselves for many reasons among them, divergent ideas, disagreement in decisions, and the distribution of resources. Mantel \& Meredith (2006) provide an analogy of such a consequence as when the Project manager attempts to move a restrictive time and estimate along to functional managers whose units are required to execute certain work on the project. Conflict then occurs between the project manager and the senior manager as technical managers argue that they are unable to perform within these restrictions, as it frustrates role of managing the project.

\section{Vertical conflicts.}

Vertical conflict takes place as different organizational hierarchy levels, such as managers and salespeople interact within the same organization. According to Mantel and Meredith (2006), the most probable triggers of vertical conflict between organizational staff and administration are:

(i) Psychological distance. Workers in this situation do not feel involved in the company and conclude that their interests are not being addressed.

(ii) Power and status. Workers feel alienated and powerless ;

(iii) Differences in value and ideology. These differences reflects an organization's core assumptions about its priorities and goals, and

(iv) Scarce resources, difference of opinion with regard to incentives, pay, and work conditions.

There is a high chance of vertical conflicts to arise when a supervisor constantly attempts to micromanage rather than allowing employees perform their duty.

Line-Staff conflicts

This occurs between support personnel and 'actual units' within a department (Stojkovic et al. 2003). The illustration demonstrated by the authors, scrutinizing the police system, would be between a police file clerk and an officer searching through for a cold case file concerning the administration of paperwork, files, evidence, etc.

Role conflicts

This arises when workers are intended to achieve incompatible demands and expectations, especially where organizations haven't clearly defined the job functions and responsibilities of their members (Celik, 2013). This may arise from an employee's having a faulty or incomplete understanding of the assignment given to them at the time. (Stojkovic et al., 2003). To explain role conflicts, Stojkovic et al. (2003) use an example, as an officer having conflict due to not fully understanding the assignment they have been given.

\section{Conflict is Inevitable}

Friction in the form of but not limited to conflicts, personality clashes, misunderstandings, and petty jealousy occur almost every time human beings interact (Ntiyakunze, 2011). This is to say that where there is a social gathering or an organization, conflict is definitely present, and therefore the project Managers must be ready to manage these frictions, or else the project won't actualize. Lack of management skills in an ever-developing industry prevents project managers and other members of an organization from handling problems effectively, leading to high chances of conflicts. Rahim (2001), Ntiyakunze (2011), (Soni et al. (2017) all confirm that;

I. Contractual conflicts are more eminent within the construction industry than any other.

II. The occurrence of disputes has risen recently and continues to rise.

III. The performance of the industry is adversely affected by disputes.

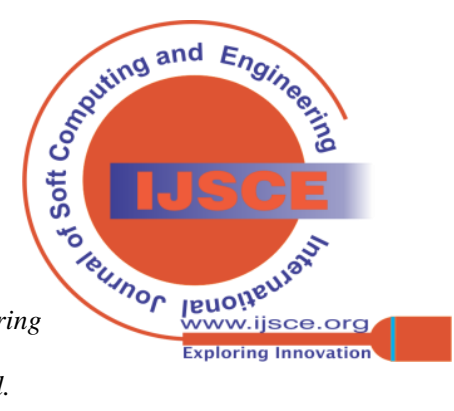




\section{RESEARCH METHODOLOGY}

This research focused on understanding conflict management situations in construction projects in Kenya, by investigating the causes, critical impacts, and management of conflicts during the implementation of these projects. Based on the argument raised by Creswell (2009), and Bryman (2012), as quantitative data on multiple variables, were collected during the same period, this study can be categorized as a survey research design. Survey research entails a cross-sectional design in which data is collected at a single point and through a questionnaire or formal interview, and seeks to measure the issues, circumstances, and problems of social phenomena that are present in society (Bryman, 2012). The researcher used both manual and electronic questionnaires to collect data from the target population. Nairobi County served as the study's research site. The criterion for selecting respondents was their technical expertise in the construction industry, taking into account the scale of the project. The target population comprised respondents randomly selected from 122 consulting firms and contracting firms registered as NCA 1 to NCA 5 within this geographical scope. These have been considered to be influential in project delivery because they are the people with the roadmap to construction project harmony, hence their ability to produce valuable and varied knowledge on conflict management practices in Kenya's construction projects. The demographic of consulting firms were drawn from the Association of Consulting Engineers of Kenya (ACEK) and the Nairobi-based Architectural Association of Kenya (AAK). The data obtained was analyzed using the Statistical Package for Social Scientists (SPSS v.21).

\section{RESEARCH FINDINGS}

\section{A. General Information of the Respondents}

The study sought to establish the general information of the respondents in terms of professional Qualifications, work positions, age, experience in the field, and level of education as well.

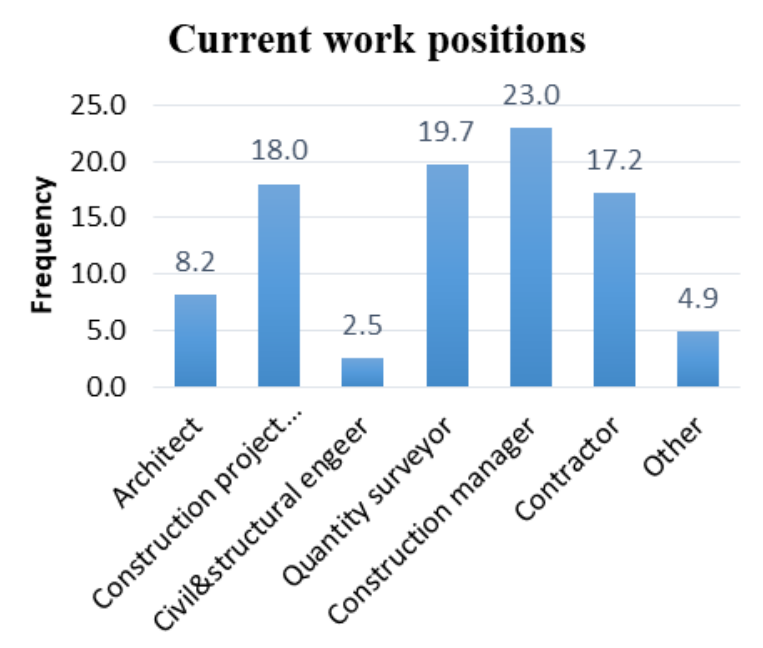

Figure 3: Current work positions of the Respondent Source: (Author, 2021)

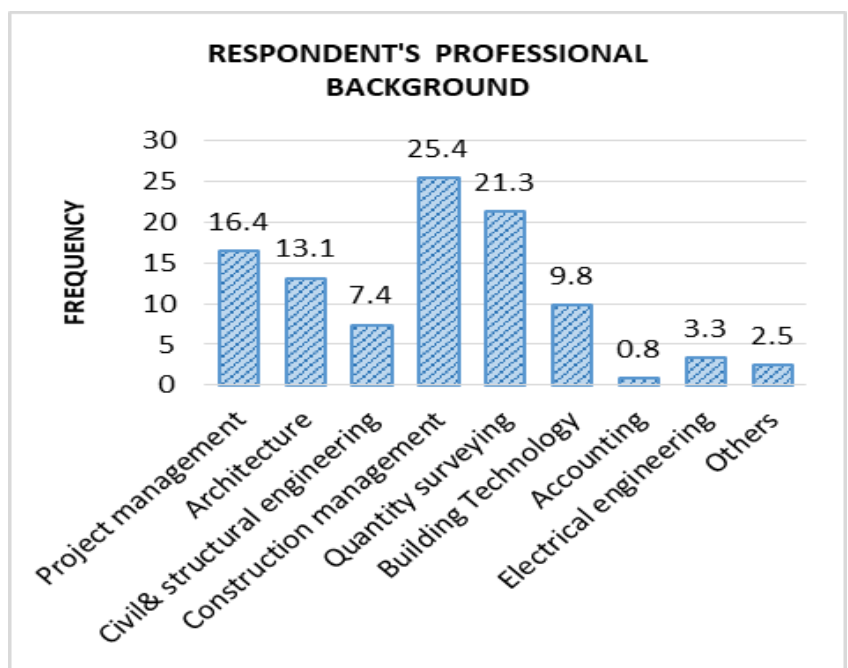

Figure 4: Respondent's professional background Source: (Author, 2021)

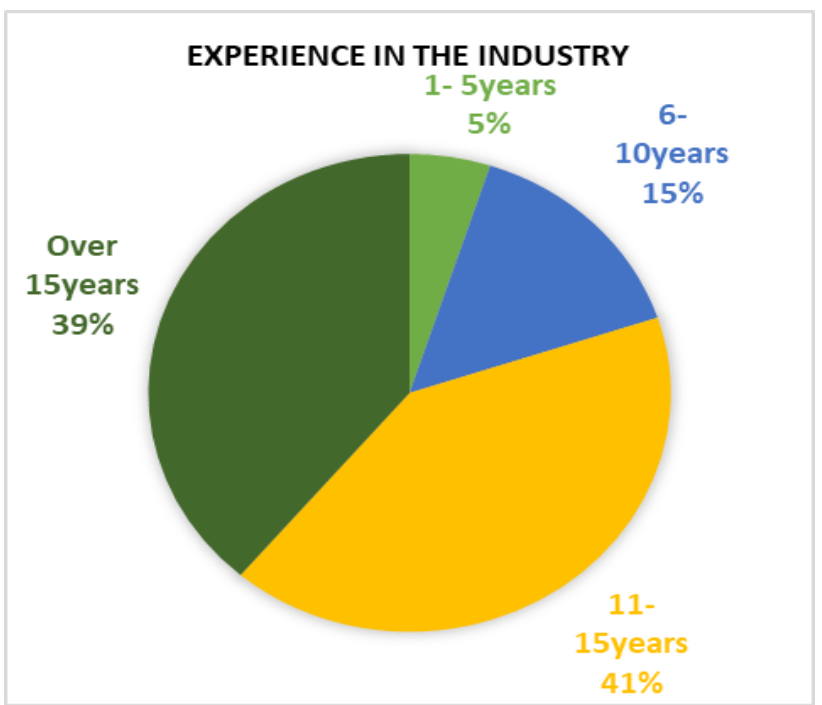

Figure 5: Industry experience of the respondents Source: (Author, 2021)

\section{Number of similar projects in the past 5 years}

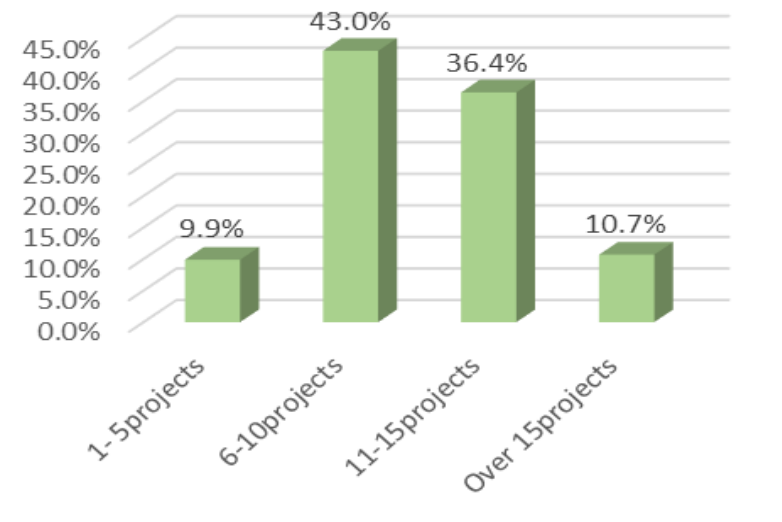

Figure 6: Number of similar projects in the past 5years Source: (Author, 2021)

Published By:

Blue Eyes Intelligence Engineering and Sciences Publication (C) Copyright: All rights reserved. 
The study sought to ascertain the general information of the respondents in terms of current work positions in the project, professional background, experience in the industry, and the number of similar projects handled within the past five years. The study found that most of the respondents are of construction management background, working as construction project managers and construction managers, with working experience between 11-15 years, and have handled between 6-10 similar projects in the past five years.

\section{B. Rate of Project Progress Interference by Factors of Conflicts}

The study also sought to explore the current practice of conflict management by evaluating the causes of conflicts from various established groups namely; the developer, consultants, contractor, and material and equipment suppliers, impacts, and expert opinions on best practices and strategies that can be used in conflict management. The study established that interference of project site operations by dysfunctional conflicts was moderate, with a mean of 3.42, displaying the inevitability of conflicts in construction projects.

\section{Project progress interference by conflicts}

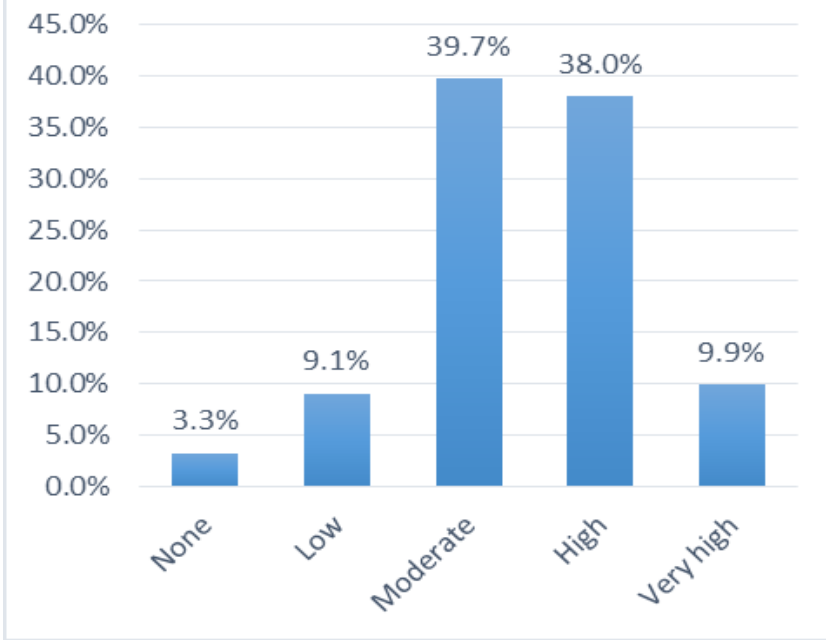

Figure 7: Project progress interference by conflicts Source: (Author, 2021)

\section{Responsibility of Conflict Management in Projects}

The study found construction project management as the most popular profession in conflict management. These findings support the assertion by Morris. M. et al (1998) that it is the project manager's duty to review and understand the dynamics of conflict in a project by considering the internal characteristics of conflicts which include perception of the goal, perception of opposing views, and actions, the definition of the problem, communication, and internal social psychology in group dynamics, and resolve it.

\section{Responsibility of conflict management}

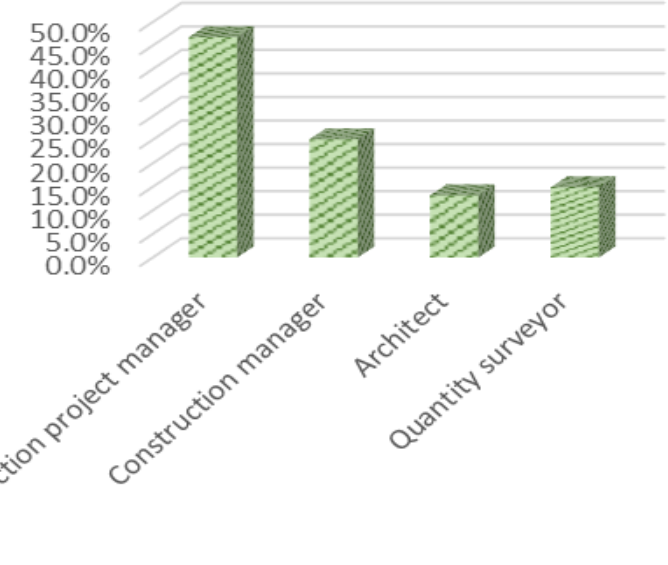

Figure 8: Responsibility of conflict management Source: (Author, 2021)

\section{Areas of Conflicts in Construction Projects}

The factors which cause conflicts in construction projects as a result of selected groups namely; clients, consultants, contractors, and material and equipment suppliers were ranked based on their frequencies following the respondents' views with the factors that scored the highest mean being ranked top factors that cause conflicts in construction projects.

Table 1: Sources of conflicts in construction projects

\begin{tabular}{|c|c|c|c|c|}
\hline Group & & $\begin{array}{l}\text { Sources of Conflicts in construction } \\
\text { projects }\end{array}$ & $\begin{array}{c}\text { Mean } \\
(\mu)\end{array}$ & Rank \\
\hline \multirow{9}{*}{ 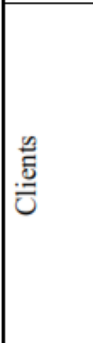 } & 1 & Delay to hand over site & 31.54 & 7 \\
\hline & 2 & Delays in progress payments & 38.41 & 1 \\
\hline & 3 & Late in revising and approving design & 23.64 & 21 \\
\hline & & documents & & \\
\hline & 4 & Compensation issues & 20.48 & 27 \\
\hline & 5 & Late delivery of material & 26.68 & 12 \\
\hline & 6 & Contractual claims & 21.88 & 26 \\
\hline & 7 & Suspension of work & 25.12 & 18 \\
\hline & 8 & Poor communication and coordination & 25.98 & 16 \\
\hline \multirow{14}{*}{ 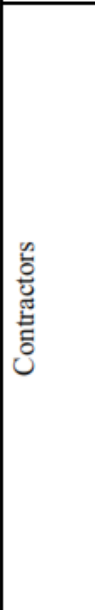 } & 9 & Delays in site mobilization & 32.06 & 6 \\
\hline & 10 & Rework due to errors during construction & 22.22 & 25 \\
\hline & 11 & Late delivery of material & 25.88 & 17 \\
\hline & 12 & Difficulties in financing project & 35.26 & 3 \\
\hline & 13 & Incompetent contractors & 28.55 & 9 \\
\hline & 14 & Frequent change of sub-contractors & 23.33 & 22 \\
\hline & 15 & Poor communication and coordination & 23.25 & 23 \\
\hline & 16 & Accidents during construction & 10.33 & 42 \\
\hline & 17 & Poor understanding of the project & 18.33 & 34 \\
\hline & 18 & Multiple projects by contractors & 23.87 & 20 \\
\hline & 19 & Poor site management and supervision & 36.05 & 2 \\
\hline & 20 & Inappropriate construction methods & 27.13 & 11 \\
\hline & 21 & $\begin{array}{l}\text { Ineffective planning and scheduling of } \\
\text { project }\end{array}$ & 32.17 & 5 \\
\hline & 22 & $\begin{array}{l}\text { Poor qualification of the contractor's } \\
\text { technical staff }\end{array}$ & 33.81 & 4 \\
\hline
\end{tabular}

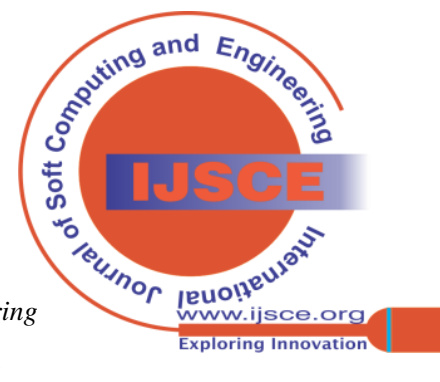




\begin{tabular}{|c|c|c|c|c|}
\hline Group & No. & $\begin{array}{l}\text { Sources of Conflicts in construction } \\
\text { projects }\end{array}$ & $\begin{array}{c}\text { Mean } \\
(\mu)\end{array}$ & Group \\
\hline \multirow{11}{*}{ 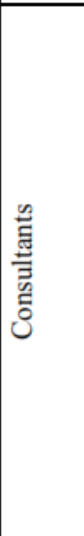 } & 23 & Complexity of the project design & 16.88 & 37 \\
\hline & 24 & Delays in producing design plans & 26.12 & 13 \\
\hline & 25 & $\begin{array}{l}\text { Mistakes and discrepancies in design } \\
\text { documents }\end{array}$ & 19.03 & 32 \\
\hline & 26 & $\begin{array}{l}\text { Delays in approving major changes on } \\
\text { scope }\end{array}$ & 20.22 & 28 \\
\hline & 27 & Improper planning & 19.26 & 31 \\
\hline & 28 & Changes on schedule and design & 19.87 & 30 \\
\hline & 29 & Inaccurate cost estimation & 12.54 & 40 \\
\hline & 30 & Inaccurate time estimation & 10.88 & 41 \\
\hline & 31 & Supply / procurement problems & 18.20 & 35 \\
\hline & 32 & Poor understanding of the project & 18.02 & 36 \\
\hline & 33 & Inadequate experience of the consultant & 19.88 & 29 \\
\hline \multirow{9}{*}{ 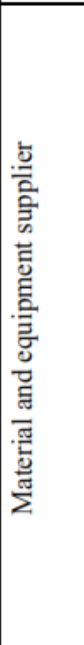 } & 34 & $\begin{array}{l}\text { Delay in material delivery from late } \\
\text { procurement }\end{array}$ & 26.02 & 15 \\
\hline & 35 & $\begin{array}{l}\text { Changes in material types and } \\
\text { specifications during construction }\end{array}$ & 15.55 & 38 \\
\hline & 36 & $\begin{array}{l}\text { Delay in manufacturing special building } \\
\text { materials }\end{array}$ & 22.63 & 24 \\
\hline & 37 & $\begin{array}{l}\text { Damage of sorted material while they are } \\
\text { needed urgently }\end{array}$ & 18.98 & 33 \\
\hline & 38 & $\begin{array}{l}\text { Late in selection of finishing materials } \\
\text { due to availability of many types in } \\
\text { Market }\end{array}$ & 13.54 & 39 \\
\hline & 39 & $\begin{array}{l}\text { Shortage of high-tech mechanical } \\
\text { equipment }\end{array}$ & 28.02 & 10 \\
\hline & 40 & Equipment breakdowns & 29.56 & 8 \\
\hline & 41 & Low level of equipment-operator's skill & 26.08 & 14 \\
\hline & 42 & $\begin{array}{l}\text { Low productivity and efficiency of } \\
\text { equipment }\end{array}$ & 24.56 & 19 \\
\hline
\end{tabular}

Source: (Author, 2021)

As depicted by the findings from the respondents, it can be deduced that conflicts may result from any of the stakeholders, with contractors having the largest contribution to conflict with 14 factors out of the 42 factors that were examined for the causes of construction conflicts. 11factors were caused by consultants, 9 factors were caused by material and equipment suppliers, while 8 were caused by Clients.

\section{E. The Level of Impacts Associated with Conflicts in Construction Projects}

The study further sought to establish the severity of the impacts of conflicts established through literature review on construction projects. The data was analyzed using the Relative Severity Index (RSI). This is represented by the following formula:

$$
R S I=\frac{\sum W}{(B \times N)} \times(100)
$$

Source: (Tam and Le, 2006)

Where;

$\mathrm{W}$ =the weighting given to each impact by respondents, ranging from 1 to 5

$\mathrm{B}=$ the highest weight (i.e. 5 in the study)

$\mathrm{N}=$ the total number of samples

After tallying the different weights assigned to each of the impacts by respondents and applying the algorithm, the impacts were ranked, with the most extreme impact having the highest relative index.

Table 2: Critical impacts of conflicts on construction projects

\begin{tabular}{|l|l|c|c|c|c|}
\hline No. & $\begin{array}{l}\text { Impact of conflicts on construction } \\
\text { projects }\end{array}$ & $* \mathbf{\Sigma W}$ & $\mathbf{B}^{* \mathbf{N}}$ & $\mathbf{R S I}$ & $\mathbf{R A N K}$ \\
\hline 1 & $\begin{array}{l}\text { Abandonment of projects leading to loss } \\
\text { of valuable time and money }\end{array}$ & 349 & 610 & 57.21 & 9 \\
\hline 2 & Increasing project cost & 527 & 610 & 86.39 & 3 \\
\hline 3 & Delays in project delivery & 549 & 610 & 90.00 & 2 \\
\hline 4 & Possibility of litigation & 405 & 610 & 66.39 & 7 \\
\hline 5 & $\begin{array}{l}\text { Feel of frustration that manifests as } \\
\text { aggressive behavior. }\end{array}$ & 382 & 610 & 62.62 & 8 \\
\hline 6 & $\begin{array}{l}\text { Loss of profitability and perhaps business } \\
\text { viability }\end{array}$ & 569 & 610 & 93.28 & 1 \\
\hline 7 & $\begin{array}{l}\text { Loss of company and professional } \\
\text { reputation }\end{array}$ & 506 & 610 & 82.95 & 4 \\
\hline 8 & $\begin{array}{l}\text { Diminution of respect between parties } \\
\text { deterioration of relationship and } \\
\text { breakdown in cooperation }\end{array}$ & 450 & 610 & 73.77 & 6 \\
\hline 9 & $\begin{array}{l}\text { Rework and relocation costs for men, } \\
\text { equipment and materials }\end{array}$ & 464 & 610 & 76.07 & 5 \\
\hline
\end{tabular}

Source: (Author, 2021)

From table 4.10 , the five most severe effects associated with conflicts as perceived by the respondents are (1) Loss of profitability and perhaps business viability (SI=93.28\%), (2) Delays in project delivery (SI=90.00\%), (3) Increasing project cost (SI=86.39\%), (4) Loss of company and professional reputation (SI=82.95\%), and (5) Rework and relocation costs for men, equipment and materials (SI=76.07\%). The least on the impact scale was Abandonment of projects leading to loss of invaluable time and money (SI=57.21\%).

\section{F. Expert Opinion on Best Practices and Strategies for Improving Project Harmony Potential}

This study sought the views of the respondents as a representation of the construction industry players regarding the best practices and strategies for improving project harmony potential through conflict management in construction projects. Respondents made 141 suggestions as to the best practices and strategies for improving project harmony potential. The scripts or responses from the respondents were carefully reviewed and grouped into themes namely: project documentation, stakeholder involvement, value-based procurement, and ICT. The classification of the proposed practices was as follows: project documents, 33 (23\%), stakeholder involvement, 35 (24\%), value-based procurement, 47 (33\%), and ICT, 26 (18\%). The strategies and practices established have been tabulated under their respective theme groups in the Table 3 Below.

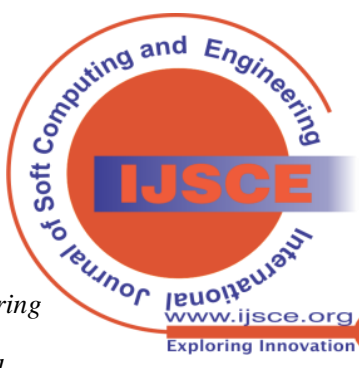


Table 3: Themed practices and strategies for conflict management

\begin{tabular}{|c|c|c|}
\hline No. & Theme group & Strategies based on expert opinion \\
\hline 1. & Project documentation & $\begin{array}{l}\text { Adequate contract documentation devoid of errors and omission; putting in place a formal } \\
\text { procedure for preventing and managing conflicts; Using simple tools such as site records } \\
\text { and daily updates opposed to MS Project; clear specifications and definition of } \\
\text { responsibilities in the contract documents; decisions at design stage to ensure proper } \\
\text { planning and review of project plans and specifications; clear contract clauses; well spelt, } \\
\text { clear and improved communication channels; definition of control parameters. }\end{array}$ \\
\hline 2. & Stakeholder involvement & $\begin{array}{l}\text { Stakeholder involvement at the early stages of the project; embracing consultation, } \\
\text { teamwork and high level of interaction during project execution; having all consultants } \\
\text { in the partnering; Proper coordination between the designers and implementers; } \\
\text { integration of all levels of project participants in conflict management; a commitment to } \\
\text { a win-win attitude; discover professional and personal goals of team members; a } \\
\text { willingness to share resources among project participants; giving timely praise and } \\
\text { recognition and awards; Establishment of sense of trust and collective responsibilities. }\end{array}$ \\
\hline 3. & Value based procurement & $\begin{array}{l}\text { Risk establishment and mitigation; planning, monitoring and evaluation; Strategic } \\
\text { management and operating styles; Strategic planning of resources; scoping with a value } \\
\text { perspective; application of compromise; endorsing project and program management } \\
\text { processes; Training of project managers to acquire essential skills in developing strategies } \\
\text { and operating styles; Employment of trained qualified Construction Managers to run } \\
\text { sites; continuous industry benchmarking; Ensuring involvement of qualified } \\
\text { professionals in the project delivery process who appreciate the importance of conflict } \\
\text { management; redefining procurement process approach from cost-based to value-based; } \\
\text { Operational workshops and contractual terms to replace non-performing firms; establish } \\
\text { of appropriate mechanisms for early identification of potential conflict issues; stakeholder } \\
\text { training in performance management }\end{array}$ \\
\hline 5. & ICT & $\begin{array}{l}\text { BIM support in decision making; increased ICT compliance; Employment of skilled } \\
\text { workers with ability to use PM tools such as MS project; adaption of new technology in } \\
\text { construction }\end{array}$ \\
\hline
\end{tabular}

Source: (Author, 2021)

\section{CONCLUSIONS}

There is widespread agreement that building sites are fraught with risk. For effective management of conflicts, it is essential to review the construction industry conflicts, and study the origin and impacts of these conflicts. Thus, this necessitated this study. This study aimed at identifying the causes and impacts of conflicts in the Kenyan construction industry and provide the best strategies and practices that can be adopted by project managers in conflict management. A survey instrument was developed and responses from 122 identified from the literature review and respondents. From the survey results, contractors have the largest contribution to conflict with 14 factors out of the 42 factors that were analyzed for the causes of construction conflicts. 11 factors were caused by consultants, 9 factors were caused by material and equipment suppliers, while 8 were caused by Clients. While there could be variations in the ranking, the findings appeared to be consistent with those of other related research.

The research found delays in progress payments by the client as the main cause of conflicts, followed by poor site management and supervision. It is vital for clients and experts in the construction industry to consider these issues in order to maximize project performance. The study ranked the impacts of conflicts using the Relative Severity Index (RSI). The biggest impact of conflicts was found to be loss of profitability and perhaps business viability, and delays in project delivery. Expert opinions regarding the best practices respondents were collected. 42 factors causing conflicts were

and strategies for improving project harmony through effective conflict management were reviewed and grouped into five classes namely; project documentation, stakeholder involvement, value-based procurement, and adoption of ICT. It is recommended that clients recruit project consultants and contractors based on expertise, experience and reputation rather than their expense. By implementing these tactics and procedures, the project manager will strengthen his leadership role and have a constructive effect on his team members' conflict resolution, paying particular attention to the known causal factors. As a result, project conflicts will be kept to a bare minimum and within reasonable limits. The study presents suitable direction for managerial interposition as well as some guidelines and tangible information that can be utilized by project managers during their practice.

\section{SCOPE FOR FUTURE RESEARCH}

This study has given recommendations based on expert opinion best strategies and practices for the management of conflicts in construction projects. Forty-two reasons for conflicts and nine critical impacts are identified. More cross-national study with a broad sample size that covers Kenya's entire construction sector is needed.

This would provide analytical data that can be applicable to the Kenyan setting.
Published By:

Blue Eyes Intelligence Engineering

and Sciences Publication

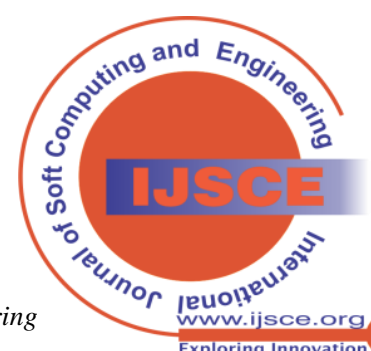


Nonetheless, it is recommended that project managers ensure that any arising conflict does not lead to claim and, as a result, to disputes and litigation. Moreover, Conflict management should be inaugurated as a component in project managers' training, both within and outside of projects. A project management regulatory body should be constituted to monitor and regulate project management practices in the Kenyan construction industry. This will improve project management discipline and retraining of project managers.

\section{REFERENCES}

1. Agwu, M. O. (2013). Conflict management and employees performance in Julius Berger Nigeria Plc. Bonny Island. International Journal of Academic Research in Management, 2(4), 125-139.

2. Bryman, A. (2012). Social Research Methods (4th Edn). New York: Oxford University Press.

3. Celik, K. (2013). The Effect of Role Ambiguity and Role Conflict on Performance of Vice Principals: The Mediating Role of Burnout. Egitim Arastirmalari-Eurasian Journal of Education Research, Vo 51.

4. Chigangacha, P., \& Haupt, T. C. (2018). Effectiveness of client involvement in construction projects: A contractor perspective. (August 2017).

5. $\quad$ Creswell, J. W. (2009). Research Design: Qualitative, Quantitative and mixed methods approach (2nd Edn). University of Nebraska, Omalla: Sage Publishers.

6. Jaffar, N., Tharim, A. H. A., \& Shuib, M. N. (2011). Procedia Engineering Factors of Conflict in Construction Industry: A Literature Review. Procedia Engineering, 20, 193-202. https://doi.org/10.1016/j.proeng.2011.11.156

7. Kingsley, E. H. (2015). Managing conflicts in construction of public projects in Ghana: (a case study of selected building project in Ashanti region). Kwame Nkrumah University of Science and Technology college of arts and built environment.

8. Leong, T. K., Zakuan, N., Zameri, M., Saman, M., Ariff, M. S., \& Tan, C. S. (2014). Using Project Performance to Measure Effectiveness of Quality Management System Maintenance and Practices in Construction Industry. The Scientific World Journal, (May 2016). https://doi.org/10.1155/2014/591361

9. Mantel, S.J., A., \& Meredith, J. R. (2006). Project Management: A Managerial Approach (6th Edn). Asia: John Wiley and Sons Inc.

10. Mbatha, S. K., Alkizim, A. O., \& Mbiti, T. K. (2021). The practice of conflict management in construction projects in Kenya. International Journal of Soft Computing and Engineering, 10(4), 1-7.

11. Mitkus, S., \& Mitkus, T. (2014). Causes of Conflicts in a Construction Industry: A Communicational Approach. Procedia Social and Behavioral Sciences, 110, 777-786. https://doi.org/10.1016/j.sbspro.2013.12.922

12. Morris, M., Williams, K., Leung, K. et al. (1998). Conflict Management Style: Accounting for Cross-National Differences. Journal of International Business Studies, 29, 729-747. https://doi.org/https://doi.org/10.1057/palgrave.jibs.8490050

13. Ntiyakunze, S. K. (2011). Conflicts in Building Projects in Tanzania: Analysis of Causes and Management Approaches.

14. Rahim, M. A. (2001). Managing Conflict In Organizations (3 rd Edn). Westport: Quorum Books.

15. Simmons, T. L. and, \& Peterson, R. S. (2000). Task Conflict and Relationship Conflict in Top Management Teams: The Pivotal Role of Intragroup Trust. Journal of Applied Psychology, Vol.85(No.1), $102-111$.

16. Soni, S., Pandey, M., \& Agrawal, S. (2017). Conflicts and Disputes in Construction Projects: An Overview. International Journal of Engineering Research and Applications, 07(06), 40-42. https://doi.org/10.9790/9622-0706074042

17. Stojkovic, S., Kalinich, D. and, \& Klofas, J. (2003). Criminal Justice Organizations: Administration and Management. Belmont, CA: Thompson/Wadsworth.

18. Tam, V.W.Y. \& Le, K. N. (2006). Environmental assessment by power spectrum. Sustainable Development through Culture and Innovation: Executive Summaries. Dubai: The Joint International Conference on Construction Culture, Innovation and Management (CCIM.

19. Vaaland, T. I. and, \& Häkansson, H. (2003). Exploring inter-organizational conflict in complex projects: Industrial

Published By:

Blue Eyes Intelligence Engineering and Sciences Publication (C) Copyright: All rights reserved.
20. Vaux, J. S. (2014). Relationship conflict in construction management and how it affects performance and profit. Washington State University.

21. Yale, D.J. and Hardcastle, C. (2003). The causes of conflicts and Disputes in the Hong Kong Construction Industry - A Transactional Cost Economics Perspective. Research Papers, Vol. 4(No. 22).

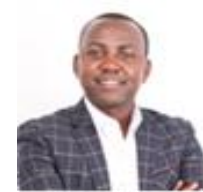

\section{AUTHORS PROFILE}

Samuel Kiilu Mbatha, Masters in Construction Project Management, Jomo Kenyatta University of Agriculture and Technology (JKUAT), Juja, Kenya. 